\title{
Cross-cultural adaptation of Hypertension Knowledge Test into European Portuguese
}

\author{
Ana C. Cabral ${ }^{1}$, Mariana Moura-Ramos ${ }^{2,3}$, Margarida Castel-Branco ${ }^{1,4}$, Margarida Caramona ${ }^{1,4}$, \\ Fernando Fernandez-Llimos ${ }^{5,6 *}$, Isabel V. Figueiredo ${ }^{1,4}$
}

\begin{abstract}
${ }^{1}$ Pharmacology and Pharmaceutical Care Laboratory, Faculty of Pharmacy, University of Coimbra, Coimbra, Portugal, ${ }^{2}$ Cognitive and Behavioural Center for Research and Intervention (CINEICC), Coimbra, Portugal, ${ }^{3}$ Faculty of Psychology and Educational Sciences, University of Coimbra, Coimbra, Portugal, ${ }^{4}$ Institute for Biomedical Imaging and life Sciences (IBILI), University of Coimbra, Coimbra, Portugal, ${ }^{5}$ Department of Social Pharmacy, Faculty of Pharmacy, University of Lisbon, Lisbon, Portugal, 'Pharmacoepidemiology \& Social Pharmacy Group, Research Institute for Medicines (iMed.ULisboa), Lisbon, Portugal
\end{abstract}

\begin{abstract}
We aim to validate a European-Portuguese version of the Hypertension Knowledge Test (HKT) questionnaire and examine its factorial structure with a confirmatory factor analysis (CFA). A process of translation and back-translation was performed. A cross-sectional study was developed in which all adult patients taking at least one antihypertensive drug were invited to participate. Data on personal and family history were collected, and the HKT, Strelec, and the Batalla questionnaires were administered. We enrolled 304 patients with a mean age of $68.12 \pm 10.83$ years. The mean score of HKT was $15.33 \pm 2.79$. CFA indicated that the construct being tested was unidimensional, and Cronbach's alpha $(\alpha=0.65)$ showed that the instrument had an acceptable internal consistency. When evaluating concurrent validity, HKT was significantly correlated with the Batalla and Strelec scores. Thus, the Portuguese version of HKT (HKT-pt-PT) can be used either in research or in clinical practice. With this version, a potential standard exists to evaluate knowledge about hypertension, which could avoid the practice of using non-validated questionnaires in Portugal and allow the cross-sectional and longitudinal comparability of studies.
\end{abstract}

Keywords: Health Knowledge/attitudes/practice. Hypertension/prevention and control. Psychometrics. Surveys and questionnaires/standards. Portugal

\section{INTRODUCTION}

Control of hypertension is of central importance in cardiovascular disease prevention strategies (Mittal, Singh, 2010). However, despite all efforts, blood pressure (BP) control remains below expectations, with control rates ranging between $12 \%$ and $50 \%$ (Mittal, Singh, 2010; Kearney et al., 2005; Wolf-Maier et al., 2003; Erdine, Aran, 2004; Pereira et al., 2009). The Physa study reported that $42.2 \%$ of Portuguese adults are hypertensive, $74.9 \%$ are being treated with antihypertensives, and $42.6 \%$ have BP within the therapeutic objectives (Polonia et al., 2014).

Correspondence: F. Fernandez-Llimos. Department of Social Pharmacy, Faculdade de Farmácia, Universidade de Lisboa. Avda. Prof. Gama Pinto, 1649-019 Lisbon - Portugal. Phone: +351919 247 736. Fax: +351 217946470. E-mail: f-llimos@ff.ul.pt
Patients' knowledge about hypertension was highlighted as one of the most important patient-related factors for poor blood pressure control (Atallah et al., 2011). Knowledge on hypertension was associated with medication adherence and subsequently with BP control (Almas et al., 2012). Patients who have been educated about the importance of treatment become more involved with their therapy (Elliott, 2008; Powers, Jalowiec, 1987). The lack of knowledge of appropriate systolic BP was identified as a risk factor for poor blood pressure control (Atallah et al., 2011; Knight et al., 2001; Alexander et al., 2003). These patients are less likely to take their medication, adopt healthy lifestyle changes, or see their physician if their blood pressure is outside the ideal range (Atallah et al., 2011; Knight et al., 2001; Alexander et al., 2003).

While many studies have evaluated patient awareness of hypertension (Pereira et al., 2009; Polonia 
et al., 2014; Joffres et al., 2013; Gee et al., 2012; Guessous et al., 2012; Macedo et al., 2007), critical elements of BP knowledge have not been adequately assessed. Developing instruments to assess knowledge is an important step to design effective intervention strategies for the control of BP. Several instruments have been used to evaluate patient knowledge about hypertension (Pineiro et al., 1997; Batalla-Martínez, 1984; Strelec, Pierin, Mion Jr., 2003), but validated instruments reporting their internal consistency and reliability are scarce. The Hypertension Knowledge Test (HKT) (Han et al., 2011) is a questionnaire initially created to assess the knowledge about hypertension in Korean-American patients. The HKT is an easy-to-use questionnaire covering several aspects of hypertension, as its etiology, diagnosis, treatment and prevention. The HKT presents probably the most robust analysis of psychometric properties, demonstrating good internal consistency $(\alpha=0.70)$, and is a sensitive and reliable instrument (Han et al., 2011).

Although in Portugal some studies have evaluated the knowledge of hypertensive patients regarding their disease and the relationship between knowledge and BP control (Prior et al., 2001; Morgado et al., 2010), no validated instrument for this purpose exists. Thus, the objective of this study was to validate the EuropeanPortuguese adaptation of the Hypertension Knowledge Test questionnaire. Specifically, this study aimed to examine its factorial structure with a confirmatory analysis and to estimate its convergent and construct validities.

\section{METHOD}

This was a cross-sectional study. Data were collected in 7 community pharmacies in the central region of Portugal and in the Hospital Infante D. Pedro in Aveiro. The study was approved by the Ethics Committee of the Faculty of Medicine of the University of Coimbra (Registration number CE_105.2013).

\section{Hypertension knowledge test}

HKT was developed based on the National HBP Education Program of the National Heart, Lung, and Blood Institute (Check Your High Blood Pressure (IQ)), a literature review and community input. HKT is a 21 -item questionnaire created to assess a patient's knowledge about hypertension. HKT comprises the following two parts: 12 true-or-false questions and 9 multiple-choice questions. The level of knowledge is calculated by assigning one point to each correct answer, obtaining a total score ranging from 0 to 21 .

\section{Translation and cross-cultural adaptation of the HKT}

A process of translation and back-translation according to international guidelines was performed (Guillemin, Bombardier, Beaton, 1993; Wild et al., 2005). After obtaining the author's permission, the original questionnaire was submitted to 3 bilingual translators who knew the goals and concepts of the study, who created 3 independent Portuguese translations. The three versions were compared in order to generate a consensus version. The reverse translation, from European-Portuguese to English, was carried out by another bilingual translator who was not involved in developing the initial version and who did not know the objectives and concepts of the study. This new English version was compared to the original version, and occasional discrepancies were corrected. Finally, a cross-culturally adapted version was obtained through a consensus meeting, attended by 2 experts in pharmacology and 1 expert in Portuguese language, who evaluated the versions' semantic, idiomatic, cultural and conceptual equivalence.

A pilot test was performed in a Portuguese population $(n=20)$ to ensure patient understanding and identify doubts and difficulties in the use of the questionnaire. The patients who participated in this face-validity phase were not further included in the study. After small adjustments based on changes proposed, we obtained the final European-Portuguese version of the HKT. Following the ISO-639 and ISO-3166, the European-Portuguese version of HKT was abbreviated as HKT-pt-PT.

\section{Batalla test}

Originally, Batalla was developed to assess patient knowledge regarding hypertension. It consists of 3 questions: "Is Hypertension a disease for life?", "Hypertension can be controlled with diet and/or medication?", and "Name 2 or more organs affected by increased blood pressure". The patient is classified as having good knowledge by correctly answering all questions (Batalla-Martínez, 1984; Pineiro et al., 1997).

\section{Strelec test}

Strelec is an instrument developed to assess patients' awareness of hypertension and its treatment (Strelec, Pierin, Mion Jr., 2003). It consists of 10 trueor-false questions. One point is attributed to each correct answer, and the final score is calculated by summing the 
points obtained. Higher scores mean a greater level of consciousness regarding hypertension.

\section{Medida de adesão aos tratamentos}

The Medida de Adesão aos Tratamentos (MAT) (Delgado, Lima, 2001) is a questionnaire developed to assess patients' adherence to medication. It consists of 7 items each rated on a six-point Likert scale, ranging from 1 ("always") to 6 ("never"). The level of adherence is obtained by adding the values of each item and then dividing by the total number of items. Higher scores mean a greater level of adherence. The classification of patients as adherent or non-adherent is made according scores near the median values.

\section{Data collection}

Data were collected between March and August 2014, and the HKT-pt-PT was applied to a sample of at least 300 patients. Inclusion criteria were adult patients taking at least one antihypertensive drug. All patients who met the inclusion criteria and were being treated by the participating pharmacies and hospital in the study were invited to participate. The interview was conducted by a trained pharmacist in a private office, where data on personal and family history were collected and the HKTpt-PT, MAT, Strelec, and the Batalla instruments were administered. Due to the use of this interview method, all participants' answers were coded, so there were no missing values.

\section{Statistical analysis}

To examine the factorial structure of the HKT-ptPT, a confirmatory factor analysis (CFA) using MPlus 6 was performed (Muthén, 1998/2010). The model was estimated using the maximum likelihood (MLMV) method, which provides robust standard errors and robust chi-square in case of deviation from normality, adjusting for mean and variance (Muthén, 1998/2010).

According to Kline (2008), samples above 300 participants are considered large and therefore adequate to use analysis such as the CFA. To evaluate overall model fit, we used the chi-square goodness-of-fit statistic, where non-significant values indicate good fit of the model to the data. In addition, we followed the recommendation that other fit indices be used to ascertain model fit (Kline, 2008), namely, the comparative fit index (CFI), the standardized root-mean-square residual (SRMR) and the root mean square error of approximation (RMSEA).
Model fit is considered adequate or good when the CFI is above 0.90 or 0.95 , the SRMR is below 0.10 , and the RMSEA is below 0.10 or 0.08 (Kline, 2008). The report of the combination of these fit indices has been recommended for a better analysis on the model fit (Hu, Bentler, 1999).

Whenever a model did not fit the data well, the model was inspected for respecification, and alternative models were also tested. The development of competing models was based on theoretical considerations and analysis of the data. Finally, the internal consistency of the HKT-pt-PT was estimated using Cronbach's alpha.

\section{RESULTS}

\section{Study participants}

There were 304 patients enrolled in the study. The mean age was $68.12 \pm 10.83$ years, and $162(53.3 \%)$ were female. The average time since hypertension diagnosis was $11.13 \pm 8.65$ years, with maximum disease duration of 50 years. In this population, $171(56.3 \%)$ had dyslipidemia, $91(29.9 \%)$ diabetes, $89(27.6 \%)$ heart disease, and 28 $(9.2 \%)$ had already had a stroke. Of the 162 women enrolled, $13(4.3 \%)$ had history of hypertension during pregnancy. The adherence mean score obtained for MAT was $5.78 \pm 0.27$.

The mean score obtained for HKT-pt-PT was $15.33 \pm 2.79$. Table I summarizes the proportion of correct responses to each item. Table II describes the frequencies of answers to the multiple choice questions.

\section{Confirmatory factor analysis}

The first CFA model included all 21 items of the HKT loaded into one global factor, Overall Knowledge of Hypertension. The model revealed a poor fit to the data, with, with $\chi^{2}(189)=226.68, p=0.03$; CFI $=0.78$; RMSEA $=0.03[90 \%$ confidence interval: $0.01 ; 0.4]$; and SRMR $=$ 0.05 . The analysis of modification indices and the evaluation of each item phrasing suggested that the introduction of error correlations (between items 8 and 11, items 13 and 15 and items 16 and 19) would improve model fit and were included in the model. The final model presented an adequate fit, with $\chi^{2}(182)=200.12, p=0.23 ; \mathrm{CFI}=0.92$; RMSEA $=0.02$ [90\% confidence interval: $0.00 ; 0.03$ ]; and $\mathrm{SRMR}=0.05$, indicating that the construct being tested, knowledge on hypertension, was unidimensional.

\section{Internal consistency and validity}

Cronbach's alpha for all items was 0.65 , and the 
TABLE I - Proportion of correct answers on the Hypertension Knowledge Test ( $\mathrm{n}=304)$

\begin{tabular}{|c|c|c|c|}
\hline \multirow{2}{*}{ Item } & \multirow{2}{*}{ Response format } & \multicolumn{2}{|c|}{ Correct answer } \\
\hline & & $\mathbf{n}$ & $\%$ \\
\hline $\begin{array}{l}\text { Q1. Se a sua mãe ou pai tiverem hipertensão o seu risco de tornar-se hipertenso } \\
\text { é maior }\end{array}$ & $\mathrm{T} / \mathrm{F}$ & 225 & 74 \\
\hline Q2. Jovens adultos não têm hipertensão & $\mathrm{T} / \mathrm{F}$ & 279 & 91.8 \\
\hline Q3. A hipertensão tem sempre sintomas & $\mathrm{T} / \mathrm{F}$ & 170 & 55.9 \\
\hline Q4. A hipertensão não põe a vida em risco & $\mathrm{T} / \mathrm{F}$ & 298 & 98 \\
\hline Q5. A pressão arterial é alta quando é igual ou superior a 140/90 mmHg & $\mathrm{T} / \mathrm{F}$ & 257 & 84.5 \\
\hline $\begin{array}{l}\text { Q6. Se tiver peso a mais tem um risco } 2 \text { a } 6 \text { vezes maior de desenvolver } \\
\text { hipertensão }\end{array}$ & $\mathrm{T} / \mathrm{F}$ & 298 & 98 \\
\hline Q7. Exercício físico regular pode ajudar a reduzir a pressão arterial & $\mathrm{T} / \mathrm{F}$ & 258 & 84.9 \\
\hline Q8. Os portugueses consomem 2 a 3 vezes mais sal ou sódio do que necessitam & $\mathrm{T} / \mathrm{F}$ & 286 & 94.1 \\
\hline Q9. Beber bebidas alcoólicas reduz a pressão arterial & $\mathrm{T} / \mathrm{F}$ & 205 & 67.4 \\
\hline Q10. A hipertensão é um problema apenas dos homens & $\mathrm{T} / \mathrm{F}$ & 303 & 99.7 \\
\hline $\begin{array}{l}\text { Q11. Hipertensão na gravidez é um problema temporário e não necessita de } \\
\text { acompanhamento após o parto }\end{array}$ & $\mathrm{T} / \mathrm{F}$ & 219 & 72 \\
\hline Q12. A pressão arterial diminui com o tempo frio & $\mathrm{T} / \mathrm{F}$ & 121 & 39.8 \\
\hline Q13. A hipertensão prejudica o seu organismo ao longo do tempo por: & $\mathrm{MC}$ & 102 & 33.6 \\
\hline Q14. Porque é que a Hipertensão é chamada um “assassino silencioso"? & $\mathrm{MC}$ & 292 & 96.1 \\
\hline Q15. Uma pessoa é diagnosticada com hipertensão se tiver: & MC & 99 & 32.6 \\
\hline Q16. Uma boa pressão arterial é: & $\mathrm{MC}$ & 297 & 97.7 \\
\hline $\begin{array}{l}\text { Q17. Qual das seguintes afirmações é verdadeira sobre os medicamentos para } \\
\text { a hipertensão: }\end{array}$ & $\mathrm{MC}$ & 95 & 31.3 \\
\hline $\begin{array}{l}\text { Q18. Qual das seguintes afirmações é falsa sobre os medicamentos para a } \\
\text { hipertensão: }\end{array}$ & $\mathrm{MC}$ & 145 & 47.7 \\
\hline $\begin{array}{l}\text { Q19. Todos os seguintes problemas de saúde podem ser provocados pela } \\
\text { hipertensão, exceto: }\end{array}$ & $\mathrm{MC}$ & 216 & 71.1 \\
\hline $\begin{array}{l}\text { Q20. Todas as seguintes afirmações são alterações que pode fazer na sua dieta } \\
\text { para reduzir a sua pressão arterial, exceto: }\end{array}$ & $\mathrm{MC}$ & 392 & 96.1 \\
\hline $\begin{array}{l}\text { Q21. Todas as seguintes alterações do estilo de vida podem ajudar a baixar a } \\
\text { sua pressão arterial, exceto: }\end{array}$ & $\mathrm{MC}$ & 204 & 67.1 \\
\hline
\end{tabular}

Abbreviation: $\mathrm{MC}=$ multiple choice; $\mathrm{T} / \mathrm{F}=$ true or false.

removal of any item would not have affected alpha significantly. The values of the alphas if an item was deleted and the item total correlations are reported in Table III.

Convergent validity was estimated by correlating the final score of the HKT-pt-PT with other measures assessing the same construct. The HKT-pt-PT was moderately and significantly correlated with the Batalla $(0.32, \mathrm{p}<0.001)$ and Strelec scores $(0.31, \mathrm{p}<0.001)$, confirming that both instruments assess correlated constructs.

Construct validity was estimated by examining differences in adherence based on knowledge of hypertension, as assessed by the HKT-pt-PT score. Based on the median (15), groups were formed: scores below the mean were considered lower knowledge, and scores above the mean were considered high knowledge. Participants with lower knowledge $(<15)$ had a mean MAT score of $5.74 \pm 0.33$, and those with higher knowledge $(\geq 15)$ had a mean score of $5.81 \pm 0.22(\mathrm{t}=-2.29, \mathrm{p}=0.04)$

\section{DISCUSSION}

Our study aimed to examine the factorial structure and validity of the European-Portuguese version of the HKT (HKT-pt-PT). To our knowledge, this is the first study using confirmatory analysis procedures to examine the 
TABLE II - Frequencies of answers of multiple choices questions

n

Q13. A hipertensão prejudica o seu organismo ao longo do tempo por:

Fazer com que tenha diabetes

33

10.9

Fazer com que ganhe peso

Danificar os seus vasos sanguíneos

6

102

114

33.6

Deixá-lo nervoso

Q14. Porque é que a Hipertensão é chamada um "assassino silencioso"?

O risco de morrer de hipertensão é baixo

Quando não há dor nem se sente doente é porque se está bem

Pode não ter sintomas e pode por a vida em risco

$\begin{array}{cc}0 & 0 \\ 7 & 2.3 \\ 293 & 96.4 \\ & \\ 72 & 23.7 \\ 4 & 1.3 \\ 92 & 30.3 \\ 99 & 32.6\end{array}$

Pressão arterial elevada em 3 ocasiões diferentes

32.6

Q16. Uma boa pressão arterial é:

Menos de 90/50 mmHg

0

297

0

Menos que 140/90 mmHg

97.7

$145 / 110 \mathrm{mmHg}$

5

0

1.6

$180 / 100 \mathrm{mmHg}$

Q17. Qual das seguintes afirmações é verdadeira sobre os medicamentos para a hipertensão:

Há muitos tipos de medicamentos para a Hipertensão

Deve ser tomada uma medicação extra quando a pressão arterial está alta

Os medicamentos não devem ser tomados se se beber álcool

Todos os medicamentos causam impotência sexual

0

Q18. Qual das seguintes afirmações é falsa sobre os medicamentos para a hipertensão:

Tomar os medicamentos para a Hipertensão durante muito tempo pode prejudicar o seu organismo

A partir do momento em que começa a tomar medicação tem de continuar a tomá-la a vida toda

Mesmo que se sinta bem tem de tomar a medicação como o prescrito

Quando sente que a dose dos medicamentos deve ser alterada, deve falar primeiro com o seu médico

Q19. Todos os seguintes problemas de saúde podem ser provocados pela hipertensão, exceto:

Ataque cardíaco

Artrite

AVC

Insuficiência Renal

Q20. Todas as seguintes afirmações são alterações que pode fazer na sua dieta para reduzir a sua pressão arterial, exceto:

Comer frango assado em vez de frito

Parar de comer batatas fritas

Evitar adicionar sal de mesa à comida

Comer fast-food ou fritos

Q21. Todas as seguintes alterações do estilo de vida podem ajudar a baixar a sua pressão arterial, exceto:

Levantar $50 \mathrm{~kg}$

Andar vigorosamente 30 minutos 3 vezes por semana

Beber menos do que 2 bebidas alcoólicas por dia 3

$\%$

.9
7.6
7.5

0

.3

\section{7} .3

(1)


TABLE III - Internal consistency reliability of the Hypertension Knowledge Test

\begin{tabular}{lcc}
\hline Item & $\begin{array}{c}\text { Item-total } \\
\text { correlation } \\
\text { coefficient }\end{array}$ & $\begin{array}{c}\text { Cronbach alfa if } \\
\text { item deleted }\end{array}$ \\
\hline Q1. Se a sua mãe ou pai tiverem hipertensão o seu risco de tornar-se hipertenso é maior & 0.30 & 0,63 \\
Q2. Jovens adultos não têm hipertensão & 0.03 & 0.66 \\
Q3. A hipertensão tem sempre sintomas & 0.03 & 0.67 \\
Q4. A hipertensão não põe a vida em risco & 0.13 & 0.65 \\
Q5. A pressão arterial é alta quando é igual ou superior a 140/90mmHg & 0.24 & 0.64 \\
Q6. Se tiver peso a mais tem um risco 2 a 6 vezes maior de desenvolver hipertensão & 0.20 & 0.65 \\
Q7. Exercício físico regular pode ajudar a reduzir a pressão arterial & 0.25 & 0.64 \\
Q8. Os portugueses consomem 2 a 3 vezes mais sal ou sódio do que necessitam & 0.30 & 0.64 \\
Q9. Beber bebidas alcoólicas reduz a pressão arterial & 0.33 & 0.63 \\
Q10. A hipertensão é um problema apenas dos homens & -0.1 & 0.63 \\
Q11. Hipertensão na gravidez é um problema temporário e não necessita de & 0.34 & 0.65 \\
acompanhamento após o parto & & 0.62 \\
Q12. A pressão arterial diminui com o tempo frio & 0.18 & 0.65 \\
Q13. A hipertensão prejudica o seu organismo ao longo do tempo por: & 0.39 \\
Q14. Porque é que a Hipertensão é chamada um “assassino silencioso"? & 0.63 \\
Q15. Uma pessoa é diagnosticada com hipertensão se tiver: & 0.65 \\
Q16. Uma boa pressão arterial é: & 0.31 & 0.64 \\
Q17. Qual das seguintes afirmações é verdadeira sobre os medicamentos para a & 0.28 & 0.63 \\
hipertensão: & & 0.63 \\
Q18. Qual das seguintes afirmações é falsa sobre os medicamentos para a hipertensão: & 0.33 & 0.62 \\
Q19. Todos os seguintes problemas de saúde podem ser provocados pela hipertensão, & 0.26 & 0.64 \\
exceto: & & 0.65 \\
Q20. Todas as seguintes afirmações são alterações que pode fazer na sua dieta para & 05 & \\
reduzir a sua pressão arterial, exceto: & & 0.63 \\
Q21. Todas as seguintes alterações do estilo de vida podem ajudar a baixar a sua pressão & 0.40 & \\
arterial, exceto: & & 0.63 \\
\hline
\end{tabular}

factor structure of the HKT, confirming the measurement model of the instrument and the unidimensional theoretical structure of the instrument (Kline, 2008). Our findings indicate that all the items contribute to the assessment of knowledge on hypertension.

The original validation was performed by administering the questionnaire to two distinct samples, in study 1 , to middle-aged hypertensives (mean age $=51.9 \pm 5.7$ years); and in study 2 , to elderly hypertensives (mean age $=70.9 \pm 5.5$ years) (Han et al., 2011). The results were presented separately for each study and for the total sample. If we compared our Cronbach's alpha $(\alpha=0.65)$ to that obtained in the total sample of the original validation $(\alpha=0.70)$, ours was lower. However, if we made the comparison with the alpha obtained in study $2(\alpha=0.62)$, which had a mean population age more similar to ours, we obtained a higher alpha. Although we obtained a Cronbach's alpha of $<0.70$, it was high enough to consider that HKT-pt-PT presents an acceptable internal consistency. One possible explanation for a Cronbach's alpha slightly below the recommended value may be the existence of some uncorrelated items. In the Portuguese version, values of item total correlation (ITC) range between -0.1 and 0.40 , and 6 items (Q2, Q3, Q4, Q10, Q14 and Q20) did not meet the cutoff of 0.15 (Nunnally, Bernstein, 1994). In study 2 of the original validation, ITC ranged between 0.11 and 0.32 , and two items, Q3 and Q6, did not meet that cutoff. The fact that these items do not contribute much to the final score may be due largely to the high percentage of correct answers that they present. This can be explained by the characteristics of the population surveyed since 
we applied the instrument to hypertensive patients under treatment, with good levels of adherence. If removal of any item would not affect alpha significantly, the removal of this item could cause this questionnaire to cease being valid for application in other contexts, particularly in a less informed population.

Analyzing the answers obtained in the multiplechoice questions, we saw that Q13, Q15, Q17 and Q18 were the questions that caused the most doubt in the patients, as less than $50 \%$ of patients provided correct answers. In Q17 ("Which of the following statements is true about HBP medications?"), approximately $48 \%$ of patients responded that "An extra medication should be taken when blood pressure is high." One possible reason for this result is that the question could be misinterpreted: the patients confused taking an extra dose of medication with taking another medication. Thus, in future applications of HKT-pt-PT, it may be useful to consider an alternative wording for this question, for example, by replacing the expression "medicação extra" with "medicação adicional".

The difficulties in accurately answering items 13, 15 and 18 may be explained by the low level of health literacy that the Portuguese population presents (Salgado et al., 2013). These results are similar to those obtained by Williams et al. (1998), where patients with poor literacy skills were less likely to answer knowledge questions correctly. Health literacy is independently correlated with disease knowledge (Gazmararian et al., 2003), and there are several studies showing that patients with lower literacy levels have lower levels of knowledge about their disease (Williams et al., 1998; American Medical Association, 1999; Mosher et al., 2012). The Portuguese population's health literacy is low. Salgado et al. (2013), measuring health literacy with the Newest Vital Sign, reported that $95 \%$ of the Portuguese respondents scored in the three lowest possible scores, indicating a notable floor effect.

Health literacy is inversely associated with age (Williams et al., 1998; Paasche-Orlow et al., 2005; Kobayashi et al., 2015); thus, patients with marginal and inadequate literacy are older than patients with adequate literacy, meaning that older patients should have worse knowledge about their disease. However, in the HKT original validation study, Han et al. (2011) showed that knowledge about hypertension increases with age and with time of disease. Similar results were obtained by Hyre et al. (2007), where patients diagnosed with hypertension for ten or more years were more likely to have a better understanding of the importance of medication-taking behaviors and their effects on long-term health. These findings suggest that personal experience with hypertension and cardiovascular disease, rather than basic knowledge, may lead to improved adherence behavior. Thus, when developing strategies to improve blood pressure control, particular characteristics of knowledge about hypertension must be taken into account, requiring the utilization of specific validated instruments.

The final score of the HKT-pt-PT was correlated with other measures assessing similar constructs, Batalla and Strelec. HKT-pt-PT was moderately and significantly correlated with both instruments, showing that the construct is correlated but not exactly the same. In fact, HKT allows us to evaluate knowledge about hypertension, not only that related to the symptoms and diagnosis of the disease but also that related to the ways of preventing and controlling high blood pressure, antihypertensive medications, and the harmful effects of hypertension over time. These multifaceted characteristics are an added value that will enable us to obtain more complete and specific information about patients' knowledge about this condition.

\section{LIMITATIONS OF THE STUDY}

A potential limitation of our study was the questionnaire application mode used. We used the interviewer-administration method, which may lead to some bias (Okamoto et al., 2002; Puhan et al., 2011). However, we considered the interview the best method to allow the inclusion of patients with very low literacy since we want the validated instrument to be applicable in every type of population, regardless of their degree of literacy.

\section{CONCLUSION}

We obtained a European-Portuguese version of the HKT (HKT-pt-PT) with acceptable internal consistency, discriminatory capacity, and predictive power regarding adherence, which can be used either in research or in clinical practice. Now a potential standard exists that could avoid the practice of using non-validated questionnaires in Portugal. This will allow the cross-sectional and longitudinal comparability of studies.

With this questionnaire, not only clinicians and researchers but also health policy decision makers can assess the gaps in patients' knowledge about hypertension and consequently develop educational activities.

Future research is warranted to assess whether knowledge evaluated by the HKT-pt-PT can be associated with process variables, such as adherence or outcome variables, including blood pressure control. 


\section{REFERENCES}

Alexander M, Gordon NP, Davis CC, Chen RS. Patient knowledge and awareness of hypertension is suboptimal: results from a large health maintenance organization. J Clin Hypertens (Greenwich). 2003;5(4):254-60.

Almas A, Godil SS, Lalani S, Samani ZA, Khan AH. Good knowledge about hypertension is linked to better control of hypertension; a multicentre cross sectional study in Karachi, Pakistan. BMC Res Notes. 2012;5(579):1-8.

American Medical Association. Health literacy: report of the Council on Scientific Affairs. Ad Hoc Committee on Health Literacy for the Council on Scientific Affairs, American Medical Association. JAMA. 1999;281(6):552-7.

Atallah A, Papouin G, Mimran C, Braunstein C, Ganty J, Larifla $\mathrm{L}$, et al. [Knowledge of hypertension among hypertensive patients in general practice, and its relation to achieving therapeutic goals: the Co-HACT study, French West Indies]. Ann Cardiol Angeiol (Paris). 2011;60(1):21-6.

Batalla-Martínez C. Cumplimiento de la prescripción farmacológica en pacientes hipertensos. Aten Primaria. 1984;1(4):185-91.

Delgado AB, Lima ML. Contributo para a validação concorrente de uma medida de adesão aos tratamentos. Psic, Saúde Doenças. 2001;2(2):81-100.

Elliott WJ. What factors contribute to the inadequate control of elevated blood pressure? J Clin Hypertens (Greenwich). 2008;10(1 Suppl 1):20-6.

Erdine S, Aran SN. Current status of hypertension control around the world. Clin Exp Hypertens. 2004;26(7/8):731-8.

Gazmararian JA, Williams MV, Peel J, Baker DW. Health literacy and knowledge of chronic disease. Patient Educ Couns. 2003;51(3):267-75.

Gee ME, Bienek A, McAlister FA, Robitaille C, Joffres M, Tremblay MS, et al. Factors associated with lack of awareness and uncontrolled high blood pressure among Canadian adults with hypertension. Can J Cardiol. 2012;28(3):375-82.

Guessous I, Bochud M, Theler JM, Gaspoz JM, PechereBertschi A. 1999-2009 Trends in prevalence, unawareness, treatment and control of hypertension in Geneva, Switzerland. PLoS One. 2012;7(6):e39877.
Guillemin F, Bombardier C, Beaton D. Cross-cultural adaptation of health-related quality of life measures: literature review and proposed guidelines. J Clin Epidemiol. 1993;46(12):1417-32.

Han HR, Chan K, Song H, Nguyen T, Lee JE, Kim MT. Development and evaluation of a hypertension knowledge test for Korean hypertensive patients. J Clin Hypertens (Greenwich). 2011;13(10):750-7.

Hu L, Bentler P. Cutoff criteria for fit indexes in covariance structure analysis: conventional criteria versus new alternatives. Struct Equation Model. 1999;6(1):1-55.

Hyre AD, Krousel-Wood MA, Muntner P, Kawasaki L, DeSalvo KB. Prevalence and predictors of poor antihypertensive medication adherence in an urban health clinic setting. J Clin Hypertens (Greenwich). 2007;9(3):179-86.

Joffres M, Falaschetti E, Gillespie C, Robitaille C, Loustalot F, Poulter N, et al. Hypertension prevalence, awareness, treatment and control in national surveys from England, the USA and Canada, and correlation with stroke and ischaemic heart disease mortality: a cross-sectional study. BMJ Open. 2013;3(8):e003423.

Kearney PM, Whelton M, Reynolds K, Muntner P, Whelton PK, He J. Global burden of hypertension: analysis of worldwide data. Lancet. 2005;365(9455):217-23.

Kline RB. Principles and practice of structural equation modeling. New York: Guilford Press; 2008.

Knight EL, Bohn RL, Wang PS, Glynn RJ, Mogun H, Avorn J. Predictors of uncontrolled hypertension in ambulatory patients. Hypertension. 2001;38(4):809-14.

Kobayashi LC, Smith SG, O'Conor R, Curtis LM, Park D, von Wagner $\mathrm{C}$, et al. The role of cognitive function in the relationship between age and health literacy: a cross-sectional analysis of older adults in Chicago, USA. BMJ Open. 2015;5(4):e007222.

Macedo ME, Lima MJ, Silva AO, Alcantara P, Ramalhinho V, Carmona J. Prevalence, awareness, treatment and control of hypertension in Portugal: the PAP study. Rev Port Cardiol. 2007;26(1):21-39.

Mittal BV, Singh AK. Hypertension in the developing world: challenges and opportunities. Am J Kidney Dis. 2010;55(3):5908. 
Morgado M, Rolo S, Macedo AF, Pereira L, Castelo-Branco M. Predictors of uncontrolled hypertension and antihypertensive medication nonadherence. J Cardiovasc Dis Res. 2010;1(4):196202.

Mosher HJ, Lund BC, Kripalani S, Kaboli PJ. Association of health literacy with medication knowledge, adherence, and adverse drug events among elderly veterans. J Health Commun. 2012;17(Suppl 3):241-51.

Muthén LK, Muthén BO. Mplus user's guide. 6.ed. Los Angeles: Muthén \& Muthén; 1998/2010.

Nunnally J, Bernstein I. Psychometric theory. 3 ed. New York: McGraw-Hill; 1994. 752 p.

Okamoto K, Ohsuka K, Shiraishi T, Hukazawa E, Wakasugi S, Furuta K. Comparability of epidemiological information between self- and interviewer-administered questionnaires. J Clin Epidemiol. 2002;55(5):505-11.

Paasche-Orlow MK, Parker RM, Gazmararian JA, NielsenBohlman LT, Rudd RR. The prevalence of limited health literacy. J Gen Intern Med. 2005;20(2):175-84.

Pereira M, Lunet N, Azevedo A, Barros H. Differences in prevalence, awareness, treatment and control of hypertension between developing and developed countries. J Hypertens. 2009;27(5):963-75.

Pineiro F, Gil V, Donis M, Orozco D, Pastor R, Merino $\mathrm{J}$. [The validity of 6 indirect methods for assessing drug treatment compliance in arterial hypertension]. Aten Primaria. 1997;19(7):372-4, 6.

Polonia J, Martins L, Pinto F, Nazare J. Prevalence, awareness, treatment and control of hypertension and salt intake in Portugal: changes over a decade: the PHYSA study. J Hypertens. 2014;32(6):1211-21.
Powers MJ, Jalowiec A. Profile of the well-controlled, welladjusted hypertensive patient. Nurs Res. 1987;36(2):106-10.

Prior C, Baía H, Martins ML, Lopes T, Vieira R. Hipertensos Que conhecimentos? Que atitudes? Rev Port Clin Geral Fam. 2001;17(1):47-55.

Puhan MA, Ahuja A, Van Natta ML, Ackatz LE, Meinert C. Interviewer versus self-administered health-related quality of life questionnaires - does it matter? Health Qual Life Outcomes. 2011;9(30):1-11.

Salgado TM, Ramos SB, Sobreira C, Canas R, Cunha I, Benrimoj SI, et al. Newest Vital Sign as a proxy for medication adherence in older adults. J Am Pharm Assoc. 2013;53(6):611-7.

Strelec MA, Pierin AM, Mion D Jr. The influence of patient's consciousness regarding high blood pressure and patient's attitude in face of disease controlling medicine intake. Arq Bras Cardiol. 2003;81(4):349-54, 3-8.

Wild D, Grove A, Martin M, Eremenco S, McElroy S, VerjeeLorenz A, et al. Principles of good practice for the translation and cultural adaptation Process for Patient-Reported Outcomes (PRO) measures: report of the ISPOR Task Force for Translation and Cultural Adaptation. Value Health. 2005;8(2):94-104.

Williams MV, Baker DW, Parker RM, Nurss JR. Relationship of functional health literacy to patients' knowledge of their chronic disease. a study of patients with hypertension and diabetes. Arch Intern Med. 1998;158(2):166-72.

Wolf-Maier K, Cooper RS, Banegas JR, Giampaoli S, Hense HW, Joffres M, et al. Hypertension prevalence and blood pressure levels in 6 European countries, Canada, and the United States. JAMA. 2003;289(18):2363-9.

Received for publication on $21^{\text {st }}$ December 2016 Accepted for publication on $18^{\text {th }}$ August 2017 